\title{
PENGARUH PENERAPAN E-SPT, PEMAHAMAN PERATURAN PERPAJAKAN, SANKSI PERPAJAKAN, DAN KUALITAS PELAYANAN TERHADAP KEPATUHAN WAJIB PAJAK
}

\author{
Rizky Pebrina'; Amir Hidayatulloh ${ }^{2}$ \\ ${ }^{1,2}$ Fakultas Ekonomi dan Bisnis Universitas Ahmad Dahlan ${ }^{\mathbf{1 , 2}}$ \\ Jalan Kapas No 9, Semaki, Umbulharjo, Kota Yogyakarta, Daerah Istimewa Yogyakarta \\ Emai: amir.hidayatulloh@act.uad.ac.id \\ diterima: 5/5/2019; direvisi: 10/5/2019; diterbitkan: 26/3/2020
}

\begin{abstract}
The purpose of this study was to determine the effect of the application of e-SPT, understanding tax regulation, taxation sanctions, and service quality on tax compliance. The population in this study are taxpayers registered with pratama tax office throughout Indonesia. The sampling technique in this study uses multiple linear regression. Respondents in the study amounted to 64 respondents, consisting of 37 respondent male sex, and 27 respondent female sex. The result obtained by this study are that tax compliance is influenced by tax sanction and service quality. However, the application of e-SPT and understanding of taxpayer regulation does not affect taxpayer compliance.
\end{abstract}

Keywords: Application of e-SPT, Understanding of Tax Regulations, Tax Sanction, Service Quality, Taxpayer Compliance

\section{PENDAHULUAN}

Pajak merupakan suatu kontribusi wajib kepada Negara yang pemungutannya dapat dipaksakan. Hal ini karena pajak dipungut berdasarkan undang-undang. Dengan membayar pajak, wajib pajak tidak mendapatkan jasa timbal balik secara langsung. Hal ini karena hasil dari pemungutan pajak digunakan untuk memenuhi kebutuhan Negara dan kemakmuran rakyat sebesarbesarnya (Undang-undang Nomor 28, 2007).

Pajak bertujuan untuk menyetarakan perekonomian dan pembangunan dari suatu Negara. Penerimaan Negara sampai dengan saat ini masih didominasi dari sektor pajak. Hal ini dapat dilihat dari penerimaan Negara pada tahun 2017 sebesar 85,6\% berasal dari sektor pajak (Kemenkeu, 2017).

Pemerintah telah melakukan beberapa cara untuk meningkatkan kepatuhan pajak. salah satu cara tersebut yaitu dengan mempermudah wajib pajak saat melakukan pengisian atau pelaporan pajak, salah satunya yaitu dengan mengembangkan SPT dalam bentuk aplikasi, atau yang dikenal dengan e-SPT.

Sesuai dengan (Peraturan Direktur Jenderal Pajak Nomor PER-01, 2016), e-SPT tahunan merupakan SPT tahunan yang berupa dokumen elektronik beserta lampiran-lampirannya yang dilaporkan menggunakan media penyimpanan elektronik. Penerapan e-SPT ini termasuk kedalam sistem pemungutan pajak yang bersifat self assessment system, dimana wajib pajak menghitung dan melaporkan sendiri pajak terutangnya kepada kantor pelayanan pajak.

Pada tahun 2018, minat masyarakat untuk menggunakan e-SPT mengalami peningkatan. Hal ini ditunjukan dengan pelaporan pajak yang menggunakan e-SPT mengalami peningkatan 21,6 persen. Pelaporan menggunakan e-SPT mencapai 8,94 juta atau sebesar 80,12 persen. Sedangkan, pelaporan pajak menggunakan SPT manual mengalami penurunan sebesar 12 persen (Saksama, 2018). Hal ini didukung oleh hasil penelitian (Handayani \& 


\section{Jurnal Ilmiah Ekonomi dan Bisnis}

Vol. 17. No.1, Maret 2020 : 1-8

EISSN : $2442-9813$

ISSN : $1829-9822$

Supadmi, 2013) yang menyatakan bahwa efektivitas penerapan e-SPT masa PPn berpengaruh pada kepatuhan wajib pajak badan di KPP Denpasar Barat. Lebih lanjut (Handayani \& Supadmi, 2013) menjelaskan bahwa penerapan e-SPT efektif untuk meningkat kepatuhan pajak.

Wajib pajak dikatakan wajib pajak patuh ketika wajib pajak tersebut memenuhi semua kewajiban perpajakannya. Menurut (Zuhdi, Topowijoyo, \& Azizah, 2015), kepatuhan perpajakan merupakan tindakan wajib pajak guna memenuhi kewajiban perpajakannya yang sesuai dengan ketentuan peraturan peundangundangan dan peraturan pelaksanaan perpajakannya yang berlaku dalam suatu Negara. Kepatuhan wajib pajak meliputi kepatuhan wajib pajak dalam mendaftarkan diri, kepatuhan menyetorkan kembali SPT, kepatuhan dalam menghitung, melaporkan, dan membayar pajak terutang, serta kepatuhan dalam pelaporan dan pembayaran tunggakan pajak.

Selain penerapan e-SPT, faktor lain yang dapat memengaruhi kepatuhan wajib pajak adalah pemahaman peraturan perpajakan (Siahaan, Basri, \& Paulus, 2015), kualitas pelayanan yang diberikan oleh petugas kantor pelayanan pajak (Lubis, 2017), dan sanksi perpajakan (Lubis, 2017).

Penelitian ini terinspirasi dari penelitian (Zuhdi et al., 2015). Perbedaan penelitian ini dengan penelitian sebelumnya adalah dengan menambah variabel yaitu kualitas pelayanan dan sanksi perpajakan. Selain menambah variabel, penelitian mengganti objek penelitian, yaitu wajib pajak orang pribadi.

Hal ini didasarkan pada data penerimaan pajak hingga maret 2018 yaitu realisasi kepatuhan wajib pajak orang pribadi sebesar 63,9 persen. Angka ini mengalami kenaikan dibandingkan dengan realisasi kepatuhan wajib pajak orang pribadi pada tahun 2017 persen. Salah satu yang memengaruhi peningkatan realisasi kepatuhan wajib pajak orang pribadi adalah tingginya jumlah pelaporan yang menggunakan elektronik (Putra, 2018).

\section{TINJAUAN PUSTAKA}

Menurut (Undang-undang Nomor 28, 2007), pajak merupakan kontribusi wajib pajak kepada Negara yang terutang oleh orang pribadi maupun badan yang pemungutannya dapat dipaksakan berdasarkan undang-undang dengan tidak mendapatkan jasa timbal balik secara langsung. Hasil pemungutan pajak digunakan untuk memenuhi keperluan Negara dan kemakmuran rakyat sebesarbesarnya. Lebih lanjut, (Undang-undang Nomor 28, 2007), wajib pajak adalah orang pribadi atau badan usaha yang meliputi pembayar pajak, pemotong pajak, dan pemungut pajak, serta pihak yang memiliki hak dan kewajiban perpajakan yang sesuai dengan ketentuan peraturan perundang-undangan.

Menurut (Mardiasmo, 2009), surat pemberitahuan merupakan surat yang digunakan wajib pajak untuk melaporkan perhitungan dan/atau pembayaran pajak, objek pajak dan/atau bukan objek pajak, dan/atau harta dan kewajiban sesuai dengan ketentuan peraturan perundangundangan. Sedangkan, e-SPT adalah SPT tahunan dalam bentuk dokumen elektronik berserta lampiran-lampirannya yang dilaporkan menggunakan media penyimpanan elektronik (Peraturan Direktur Jenderal Pajak Nomor PER-01, 2016).

Pemahaman peraturan perpajakan adalah suatu proses yang dilakukan oleh wajib pajak untuk memahami dan mengetahui tentang peraturan, undangundang serta tata cara perpajakan, serta mengimplementasikan pada kegiatan perpajakan. Kegiatan perpajakan meliputi pembayaran pajak, pelaporan SPT, dan 
lain sebagainya. Jika individu telah memahami dan mengerti mengenai perpajakan maka tingkat kepatuhan wajib pajak pun meningkat (Adiasa, 2013).

Menurut (Boediono, 2013), pelayanan pajak merupakan proses bantuan kepada wajib pajak dengan cara-cara teretntu yang membutuhkan kepekaan dan hubungan interpersonal. Hal ini dilakukan guna mencapai suatu kepuasaan dan keberhasilan. Menurut (Kusuma, 2016), pelayanan pajak bertujuan untuk memberikan kenyamanan, keamanan, dan kepastian bagi wajib pajak saat memenuhi kewajiban dan haknya pada bidang perpajakan.

$$
\text { Kualitas pelayanan pajak }
$$
merupakan salah satu cara yang dilakukan pemerintah untuk meningkatkan kepatuhan wajib pajak dalam memenuhi kewajibannya. Sehingga, petugas pajak diharapkan memiliki kompetensi yang baik terkait dengan segala hal yang berhubungan dengan perpajakan di Indonesia (Kusuma, 2016).

Sanksi perpajakan merupakan jaminan bahwa ketentuan peraturan perundang-undangan perpajakan (norma perpajakan) akan dituruti/ditaati/dipatuhi, dengan kata lain sanksi perpajakan merupakan alat pencegah agar wajib pajak tidak melanggar norma perpajakan (Mardiasmo, 2009). Sanksi perpajakan terjadi karena adanya pelanggaran pada peraturan perundang-undangan perpajakan. Sehingga, apabila wajib melakukan pelanggaran maka wajib pajak dapat dikenai hukuman (Resmi, 2014).

Kebijakan berupa pengenaan sanksi bertujuan untuk mendidik dan menghukum. Tujuan mendidik agar wajib pajak yang dikenakan sanksi berubah menjadi lebih baik dan lebih mengetahui hak dan kewajibannya.
Sehingga, adanya pengenaan sanksi diharapkan wajib pajak tidak melakukan kesalahan yang berulang. Sedangkan, menghukum dimaksudkan untuk menghukum. Oleh karena itu, diharapkan wajib pajak yang terhukum mengetahui akibat dari kesalahan yang dilakukan dan tidak lagi mengulangi kesalahannya (Resmi, 2014).

Sanksi perpajakan terdiri dari dua, yaitu sanksi administrasi dan sanksi pidana. Sanksi administrasi dikenakan pada wajib pajak yang tidak memenuhi peraturan perpajakan atau melakukan pelanggaran terhadap aturan perpajakan yang berlaku. Sanksi administrasi berupa pembayaran kerugian kepada Negara yang berupa bunga, denda, atau kenaikan. Sanksi pidana berupa denda pidana, kurungan, dan penjara (Mardiasmo, 2009); (Kusuma, 2016).

Kepatuhan wajib pajak merupakan kesadaran diri wajib pajak untuk melaporkan dan menyetorkan pajak terutangnya sesuai dengan peraturan yang berlaku. Lebih lanjut, (Peraturan Menteri Keuangan Nomor 192/PMK.03, 2007) pasal 1 menyatakan bahwa wajib pajak dikatakan patuh ketika memiliki kriteria sebagai berikut (1) wajib pajak tepat waktu dalam menyampaikan surat pemberitahuan, (2) wajib pajak tidak memiliki tunggakan pajak untuk semua jenis pajak, kecuali tunggakan pajak yang telah memeroleh izin mengangsur atau menunda pembayaran pajak, (3) laporan keuangan diaudit oleh akuntan publik atau lembaga pengawasan keuangan pemerintah dengan pendapat wajar tanpa pengecualian selama 3 (tiga) tahun berturut-turut, (4) tidak pernah dipidana karena melakukan tindak pidana di bidang perpajakan berdasarkan putusan pengadilan yang telah mempunyai kekuatan hukum tetap dalam jangka waktu 5 (lima) tahun terakhir.

Berdasarkan uraian latar belakang, tinjauan pustaka, maka rerangka penelitian ini disajikan sebagai berikut: 


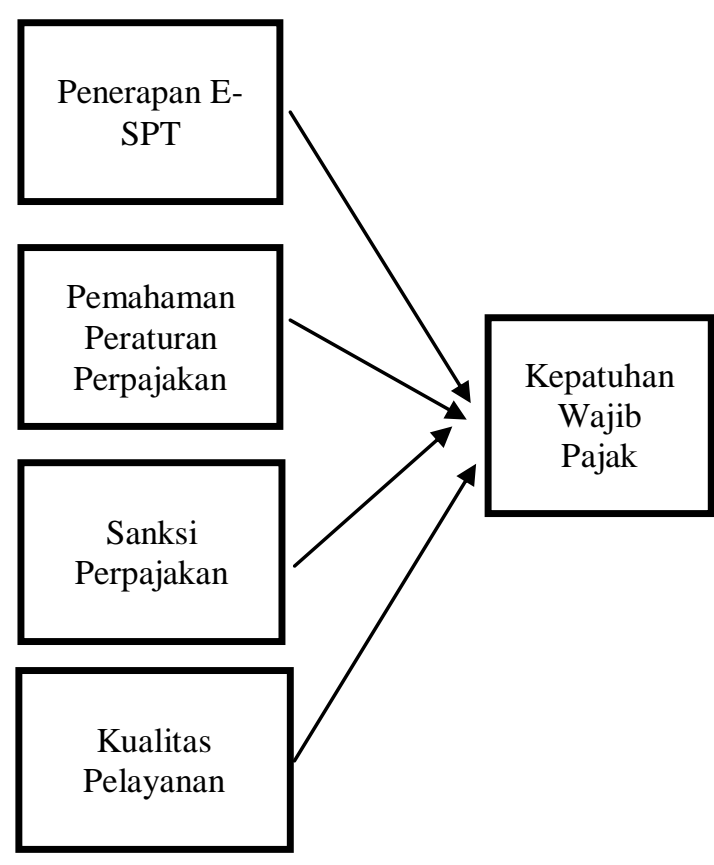

Gambar 1. Rerangka Penelitian

Pengaruh Penerapan e-SPT Terhadap Kepatuhan Wajib Pajak.

Berdasarkan (Peraturan Direktur Jenderal Pajak Nomor PER-01, 2016), tujuan pemerintah mengembangkan eSPT adalah untuk mempermudah wajib pajak dalam melaporkan pajaknya. Sehingga, dengan adanya kemudahaan yang diberikan wajib pajak lebih semakin termotivasi untuk membayar pajak.

Penelitian (Zuhdi et al., 2015), menyatakan bahwa salah satu faktor yang dapat memengaruhi kepatuhan wajib adalah penerapan e-SPT. Hal ini didukung oleh (Lingga, 2013), yang memperoleh hasil bahwa penerapan eSPT berpengaruh terhadap kepatuhan wajib pajak. Dari uraian sebelumnya, maka hipotesis pertama penelitian ini adalah sebagai berikut.

$\mathrm{H}_{1}$ : Penerapan E-SPT berpengaruh terhadap kepatuhan wajib pajak

Pengaruh Pemahaman Perpajakan Terhadap Kepatuhan Wajib Pajak

Pemahaman peraturan perpajakan merupakan suatu proses dimana wajib pajak memahami dan mengetahui tentang peraturan, undang-undang serta tata cara perpajakan, serta menerapkannya pada kegiatan perpajakan (Adiasa, 2013). Lebih lanjut (Adiasa, 2013) menyatakan bahwa adanya pemahaman mengenai tata cara pemungutan pajak dan sistem yang digunakan pemerintah dalam pemungutan pajak memberikan gambaran yang jelas kepada wajib pajak dalam pelaporan pajaknya. Oleh karena itu, pemahaman pajak dapat dikatakan sebagai salah satu faktor penentu dalam keberhasilan program-program pajak yang diselenggarakan oleh pemerintah. Pernyataan ini didukung oleh hasil penelitian (Siahaan et al., 2015), pengetahuan peraturan perpajakan berpengaruh terhadap kepatuhan wajib pajak. Dari uraian sebelumnya, maka hipotesis kedua penelitian ini adalah sebagai berikut.

$\mathrm{H}_{2}$ : Pemahaman perpajakan berpengaruh terhadap kepatuhan wajib pajak

Pengaruh Sanksi Pajak Terhadap Kepatuhan Wajib Pajak

Menurut (Resmi, 2014), tujuan kebijakan berupa pemberian sanksi adalah mendidik dan menghukum. Mendidik berarti bahwa pengenaan sanksi diharapkan menjadikan wajib lebih baik dan lebih mengetahui hak dan kewajibannya. Sedangkan, menghukum berarti pemberian sanksi bertujuan untuk menghukum. Hal ini dilakukan dengan tujuan agar wajib pajak yang pernah dihukum dapat mengetahui akibat dari kesalahnya. Sehingga, mendidik dan menghukum memiliki tujuan untuk membuat wajib pajak tidak mengulangi kesalahan yang sama.

Menurut (Lubis, 2017), pemerintah menerapkan sanksi sebagai alat untuk mengendalikan wajib pajak agar patuh terhadap peraturan dan memiliki keinginan untuk membayar pajak secara sukarela. Dari uraian sebelumnya, maka 
hipotesis ketiga penelitian ini adalah sebagai berikut:

$\mathrm{H}_{3}$ : Sanksi perpajakan berpengaruh terhadap kepatuhan wajib pajak

Pengaruh Kualitas Pelayanan Terhadap Kepatuhan Wajib Pajak

Menurut (Kusuma, 2016) tujuan pelayanan pajak adalah memberikan kenyaman, keamanan, dan kepastian bagi wajib pajak dalam pemenuhan kewajiban dan haknya di bidang perpajakan. Kualitas pelayanan pajak merupakan salah satu faktor yang dapat meningkatkan minat wajib pajak untuk memenuhi kewajiban perpajakannya (Kusuma, 2016).

Adanya pelayanan pajak yang berkualitas, maka wajib pajak akan terdorong dengan sendirinya untuk melaporkan pajaknya. Pelayanan yang berkualitas meliputi pemberian fasilitas yang menunjang, mempermudah wajib pajak, serta pelayanan dari pegawai. Sehingga, dengan adanya pelayanan yang baik maka akan meningkatkan kepatuhan wajib pajak (Lubis, 2017). Dari uraian sebelumnya, maka hipotesis keempat penelitian ini adalah sebagai berikut.

$\mathrm{H}_{4}$ : Kualitas pelayanan berpengaruh terhadap kepatuhan wajib pajak

\section{METODE PENELITIAN}

Jenis penelitian ini adalah penelitian kuantitatif. Variabel dependen dalam penelitian ini adalah kepatuhan wajib pajak. Sedangkan, variabel independen dalam penelitian adalah penerapan E-SPT, pemahaman peraturan perpajakan, sanksi perpajak, dan kualitas pelayanan.

Populasi penelitian ini adalah wajib pajak orang pribadi yang terdaftar di Kantor Pelayanan Pajak (KPP) diseluruh Indonesia. Teknik pengambilan sampel dalam penelitian ini menggunakan convience sampling.
Data penelitian ini diperoleh dengan menyebarkan kuesioner secara langsung kepada responden. Variabel kepatuhan pajak diukur menggunakan empat pernyataan, variabel pemahaman peraturan perpajakan diukur menggunakan tujuh item pernyataan, variabel sanksi pajak diukur dengan menggunakan enam item pernyataan, serta kualitas pelayanan diukur menggunakan sebelas item pernyataan.

Pernyataan untuk variabel kepatuhan wajib pajak, pemahaman peraturan perpajakan, sanksi perpajakan, dan kualitas pelayanan diadopsi dari (Alfiah, 2014). Sedangkan, penerapan eSPT diukur dengan menggunakan sembilan item pernyataan yang diadopsi dari (Abduh, 2015). Masing-masing variabel menggunakan skala likert lima point, 1 (sangat tidak setuju), 2 (sangat setuju), 3 (ragu-ragu), 4 (setuju), dan 5 (sangat setuju).

Peneliti menyebar kuesioner kepada responden secara langsung. Kuesioner yang terkumpul berjumlah 70 kuesioner, akan tetapi hanya 64 kuesioner yang dapat diolah lebih lanjut. Hal ini karena enam kuesioner tidak diisi secara lengkap oleh responden. Teknik analisis data yang digunakan dalam penelitian ini adalah analisis regresi berganda.

\section{HASIL DAN PEMBAHASAN}

Responden dalam penelitian ini berjumlah 64 responden. Responden dalam penelitian ini didominasi oleh responden berjenis kelamin laki-laki sebanyak 37 responden $(57,8 \%)$, sedangkan 27 responden berjenis kelamin perempuan.

Usia responden dalam penelitian ini didominasi oleh usia 18-25 tahun (30 responden). Sedangkan, responden yang berusia 26-30 tahun sejumlah 16 responden, usia 31-40 tahun berjumlah 8 responden, sedangkan responden yang berusia diatas 40 tahun sejumlah 10 responden. 


\section{Jurnal Ilmiah Ekonomi dan Bisnis}

Vol. 17. No.1, Maret 2020 : 1-8

EISSN : $2442-9813$

ISSN : $1829-9822$

Tingkat pendidikan responden dalam penelitian ini didominasi oleh tingkat pendidikan SMA (23 orang). Sedangkan 29 responden memiliki tingkat pendidikan strata 1 (S1), strata dua atau strata 3 (S2/S3) berjumlah 4 responden, sedangkan 8 responden memiliki tingkat pendidikan diploma.

$$
\text { Hasil pengujian hipotesis }
$$

disajikan pada tabel 1. Tabel 1 menunjukan bahwa nilai adjusted $R$ Square sebesar 0,22. Hal ini berarti bahwa variabilitas kepatuhan wajib pajak sebesar $22 \%$ dapat dijelaskan oleh variabel penerapan e-spt, pemahaman peraturan perpajakan, sanksi perpajakan, dan kualitas pelayanan.

Tabel 1. Hasil Pengujian Hipotesis

\begin{tabular}{|l|l|l|l|}
\hline $\begin{array}{l}\text { Variabel } \\
\text { Independen }\end{array}$ & $\begin{array}{l}\text { Koefisien } \\
\text { Regresi }\end{array}$ & Signifikasi & Kesimpulan \\
\hline $\begin{array}{l}\text { Penerapan } \\
\text { E-SPT }\end{array}$ & 0,013 & 0,872 & $\begin{array}{l}\text { Tidak } \\
\text { terdukung }\end{array}$ \\
\hline $\begin{array}{l}\text { Pemahanam } \\
\text { peraturan } \\
\text { Perpajakan }\end{array}$ & 0,012 & 0,895 & $\begin{array}{l}\text { Tidak } \\
\text { Terdukung }\end{array}$ \\
\hline Sanski Pajak & 0,191 & 0,008 & Terdukung \\
\hline $\begin{array}{l}\text { Kualitas } \\
\text { Pelayanan }\end{array}$ & 0,137 & 0,028 & Terdukung \\
\hline Konstanta: 12,788 & & \\
\hline Variabel dependen: Kepatuhan Wajib pajak \\
\hline Adjusted R-Square: 0,220 \\
\hline F Statistik: 5,431 \\
\hline Signifikasi: 0,001 \\
\hline
\end{tabular}

Sumber: data primer diolah (2018)

Tabel 1 menunjukan hasil uji $\mathrm{F}$ diperoleh tingkat signifikasi 0,001 yang lebih kecil dibandingkan nilai alpha 0,05 . Hal ini berarti bahwa minimal terdapat satu variabel independen (penerapan e-spt, pemahaman peraturan perpajakan, sanksi perpajakan, serta kualitas pelayanan) yang berpengaruh terhadap kepatuhan wajib pajak.

Tabel 1 juga menunjukan bahwa penerapan e-SPT tidak berpengaruh terhadap kepatuhan wajib pajak. Hal ini dapat dilihat dari nilai signifikasi 0,872 yang lebih besar dari 0,05. Atau dengan kata lain, hipotesis pertama $\left(\mathrm{H}_{1}\right)$ penelitian ini tidak terdukung. Hal ini karena wajib pajak sulit memahami penggunaan aplikasi e-spt. Selain itu, masih terbatasnya akses internat di beberapa wilayah Indonesia. Pernyataan ini didukung oleh hasil penelitian (Azyarah, 2017), yang menyatakan bahwa sistem e-spt tidak berpengaruh terhadap kepatuhan wajib pajak.

Pemahaman peraturan perpajakan tidak berpengaruh terhadap kepatuhan wajib pajak. Atau dengan kata lain, hipotesis kedua $\left(\mathrm{H}_{2}\right)$ penelitian ini tidak terdukung. Hal ini dapat dilihat dari nilai signifikasi 0,895 yang lebih besar dibandingkan dengan 0,05. Oleh karena itu, hasil penelitian ini menunjukan bahwa semakin tinggi atau rendahnya pemahaman wajib pajak tidak akan memengaruhi kepatuhan wajib pajak. Pernyataan ini didukung oleh hasil penelitian (Arisandy, 2017), menyatakan bahwa pemahaman perpajakan tidak berpengaruh terhadap kepatuhan wajib pajak.

Kepatuhan wajib pajak dipengaruhi oleh sanksi perpajakan. Hal ini dapat dilihat dari nilai signifikasi 0,008 yang lebih kecil dibandingkan dengan 0,05. Atau dengan kata lain, hipotesis ketiga $\left(\mathrm{H}_{3}\right)$ penelitian ini terdukung. Dengan keterdukungan hipotesis ini menunjukan bahwa wajib pajak telah sadar dengan kewajibannya untuk membayar pajak. Selain itu, dengan adanya sanksi yang dianggap merugikan bagi wajib pajak apabila tidak membayar pajak atau membayar pajak namun tidak sesuai dengan seharusnya, maka wajib pajak dapat dikenakan sanksi baik sanksi berupa denda maupun sanksi yang berupa kurungan penjara. Hal ini didukung oleh hasil penelitian (Lubis, 2017); (Irmawati \& Hidayatulloh, 2019) yang menyatakan bahwa sanksi perpajakan berpengaruh terhadap kepatuhan wajib pajak.

Selain sanksi perpajakan, kepatuhan wajib pajak juga dipengaruhi oleh kualitas pelayanan. Hal ini dapat dilihat dari nilai signifikasi 0,028 yang 
Jurnal Ilmiah Ekonomi dan Bisnis

Vol. 17. No.1, Maret $2020: 1-8$

EISSN : $2442-9813$

ISSN : $1829-9822$

lebih kecil dibandingkan dengan 0,05. Atau dengan kata lain, hipotesis keempat $\left(\mathrm{H}_{4}\right)$ penelitian ini terdukung. Dengan keterdukungan hipotesis ini menunjukan bahwa ketika masyarakat merasa nyaman dengan pelayanan yang diberikan pemerintah, maka minat masyarakat untuk membayar pun akan meningkat. Pernyataan ini didukung oleh hasil penelitian (Lubis, 2017), yang menyatakan bahwa kualitas pelayanan berpengaruh terhadap kepatuhan wajib pajak.

\section{KESIMPULAN DAN SARAN}

Faktor yang dapat memengaruhi kepatuhan wajib pajak antara lain sanksi perpajakan dan kualitas pelayanan. Sehingga, dengan adanya sanksi yang dapat menimbulkan kerugian bagi wajib pajak yang tidak melaporkan atau melaporkan pajak namun tidak sesuai dengan seharusnya, maka wajib pajak akan terdorong untuk membayar pajak. Selain itu, ketika pihak pemerintah atau fiskus menyediakan pelayanan yang baik, maka wajib pajak juga akan terdorong untuk membayar pajak. Namun, penerapan e-spt dan pemahaman peraturan perpajakan tidak berpengaruh terhadap kepatuhan wajib pajak.

Penelitian ini tidak terlepas dari suatu keterbatasan. Keterbatasan yang melekat pada penelitian ini adalah (1) penelitian ini belum membedakan wajib pajak orang pribadi yang melakukan pekerjaan bebas dengan pegawai negeri sipil maupun karyawan, dan (2) penelitian ini menggunakan metode survei. Sehingga penelitian ini memiliki validitas internal yang rendah.

Dari keterbatasan yang dimiliki penelitian ini, maka penelitian selanjutnya disarankan membedakan antara wajib pajak yang menjalankan pekerjaan bebas, pegawai negeri sipil, dan karyawan. Penelitian selanjutnya juga dapat menggunakan metode kualitatif atau ekperimen. Hal ini dilakukan agar penelitian selanjutnya dapat memiliki validitas yang tinggi.

\section{DAFTAR PUSTAKA}

Abduh, A. M. (2015). Kuesioner pengaruh penerapan e-SPT terhadap efisiensi pengisian SPT. Universitas Hasannudin.

Adiasa, N. (2013). Pengaruh Pemahaman Peraturan Pajak Terhadap Kepatuhan Wajib Pajak Dengan Preferensi Risiko Sebagai Variabel Moderating. Universitas Negeri Semarang.

Alfiah, I. (2014). Kesadaran Perpajakan, Sanksi Perpajakan, Sikap Fiskus,Lingkunga Pajak, Pengetahuan Perpajakan Pajak,Persepsi Efektifitas Sistem Perpajakan, Kemauan Membayar Pajak Terhadap Kepatuhan Wajib pajak Orang Pribadi di DPPKAD Grobogan-Purwodadi. Universitas Muria Kudus.

Arisandy, N. (2017). Pengaruh Pemahaman Wajib Pajak, Kesadaran Wajib Pajak Dan Sanksi Pajak Terhadap Kepatuhan Wajib Pajak Orang Pribadi Yang Melakukan Kegiatan Bisnis Online Di Pekanbaru. Jurnal Ilmiah Ekonomi Dan Bisnis, 14(1).

Azyarah, F. B. (2017). Pengaruh Penerapan Sistem e-Registration, E-SPT, dan e-Filling Terhadap Kepatuhan Wajib Pajak Orang Pribadi. Universitas Dian Nuswantoro.

Boediono, B. (2013). Pelayanan Prima Perpajakan. Jakarta: Rineka Cipta.

Handayani, K. P., \& Supadmi, N. L. (2013). Pengaruh Efektivitas E -Spt Masa Ppn Pada Kepatuhan Wajib Pajak Badan. 1, 19-38. 


\section{Jurnal Ilmiah Ekonomi dan Bisnis}

Vol. 17. No.1, Maret 2020 : 1-8

EISSN : $2442-9813$

ISSN : $1829-9822$

Irmawati, J., \& Hidayatulloh, A. (2019). Determinan Kepatuhan Wajib Pajak UMKM dI Kota Yogyakarta. Jurnal Sistem Informasi, Keuangan, Auditing dan Perpajakan, 3(2), 112-121.

Kemenkeu. (2017). Retrieved from http://www.kemenkeu.go.id/apbn 2017

Kusuma, K. C. (2016). Pengaruh Kualitas Pelayanan Pajak, Pemahaman Peraturan Perpajakan Serta Sanksi Perpajakan Terhadap Kepatuhan Wajib Pajak Orang Pribadi Dalam Membayar Pajak Tahun 2014 (Studi Kasus pada Wajib Pajak yang Terdaftar di Kantor Pelayanan Penyuluhan danKonsultas. Universitas Negeri Yogyakarta.

Lingga, I. S. (2013). Pengaruh Penerapan e-SPT Terhadap Kepatuhan Pajak: Studi Empiris Terhadap Pengusaha Kena Pajak di Wilayah KPP Pratama " X " Jawa Barat I Ita Salsalina Lingga Pendahuluan. Jurnal AKuntansi, 5(1), 50-60.

Lubis, R. H. (2017). Pengaruh Kualitas Pelayanan Perpajakan, dan Sanksi Perpajakan Terhadap Kepatuhan Wajib Pajak di KPP Pratama Medan Belawan. Jurnal Konsep Bisnis Dan Manajemen, 4(1), $50-60$. https://doi.org/10.1037/a0015270 .Timeline

Mardiasmo. (2009). Perpajakan, Edisi Revisi 2009. Yogyakarta: Andi Offset.

Peraturan Direktur Jenderal Pajak Nomor PER-01 Tahun 2016 Tentang Tata Cara Penerimaan dan Pengelolaan Surat Pemberitahuan Tahunan
Peraturan Menteri Keuangan Nomor 192/PMK.03 Tahun 2007 Tentang Tata Cara Penetapan Wajib Pajak Dengan Kriteria Tertentu Dalam Rangka Pengembalian Pendahuluan Kelebihan Pembayaran Pajak

Putra, A. D. (2018). Rasio Kepatuhan Pelaporan SPT Wajib Pajak Orang Pribadi Meningkat. Retrieved from https://ekonomi.kompas.com/read/ 2018/04/02/180752626/rasiokepatuhan-pelaporan-spt-wajibpajak-orang-pribadi-meningkat

Resmi, S. (2014). Perpajakan: Teori dan kasus. Jakarta: Salemba Empat.

Saksama. (2018). Retrieved from www.pajak.go.id

Siahaan, M. E. U., Basri, Y. M., \& Paulus, S. (2015). Pengaruh Persepsi Pelaksanaan Sensus Pajak Nasional, Pengetahuan Dan Pemahaman Peraturan Perpajakan, dan Kesadaran Perpajakan Terhadap Kepatuhan Wajib Pajak Orang Pribadi (WPOP) Pada KPP Pratama Pekanbaru Senapelan. Jom Fekon, 2(2), 1-15.

Undang-undang Nomor 28 Tahun 2007 Tentang Ketentuan Umum dan Tata Cara Perpajakan

Zuhdi, F. A., Topowijoyo, \& Azizah, D. F. (2015). Pengaruh Penerapan ESPT dan Pengetahuan Perpajakan Terhadap Kepatuhan Wajib pajak (Studi Kasus Pengusaha Kena Pajak Yang Terdaftar di KPP Pratama Singosari). Jurnal Perpajakan (JEJAK), 7(1), 193206. https://doi.org/10.1007/978-3531-92674-2_11 